\title{
Search for thermotolerant coliforms in the fillets of frozen fish produced in cote d'ivoire and intended for export
}

\author{
Abdelsalam Adoum Doutoum ${ }^{1 *}$, Abdelsalam Tidjani ${ }^{2}$, Marius K. Somda ${ }^{3}$, Alfred S. Traore \\ ${ }^{3}$, Vessaly Kallo ${ }^{4,5}$, Alioune Ndiaye ${ }^{5}$, Coumba Faye ${ }^{5}$, Hamadou Abba ${ }^{6}$, Roumane Moukhtar \\ 1, Malang Seydi ${ }^{5}$ and Bhen Sikina Toguebaye ${ }^{7}$
}

1 Higher National Institute of Science and Technology of Abeche (Chad) 2 Faculty of Human Health Sciences of N'Djamena (Chad) 3 Center for Research in Biological, Food and Nutritional Sciences (CRSBAN), Department of Biochemistry-Microbiology (DBM), Training and Research Unit in Life and Earth Sciences (UFR/SVT), Ouaga University1 Pr Joseph KI-ZERBO, 03 BP 7021, Ouagadougou 03, BURKINA FASO 4 Central Laboratory for Hygiene and Agro-Industry of Ivory Coast (LCHAI) 5 Inter-State School of Veterinary Sciences and Medicine (EISMV)-Hygiene and Foodstuffs Industry of Animal Origin (HIDAOA) (Senegal) 6 Faculty of Health Sciences, Adam Barka University, Abeche, Chad, B.P 11737 Department of Animal Biology; Cheikh Anta Diop University of Dakar (Senegal).

\begin{abstract}
This study is part of the search for solutions to the problems encountered in the manufacture and export of fish fillets. The production of fish fillets is mainly marked by a little mechanization. Thus, it is subjected to strong manipulation by the personnel, source of contamination. As a result, the search for thermotolerant coliforms, most of which are of fecal origin, makes it possible to assess the level of contamination of products and to judge the effectiveness of the hygiene measures taken by the fishnet production units.

190 preventive samples from 4 companies were studied. A survey was conducted to categorize the companies. Subsequently, the thermotolerant coliforms were counted on the violet crystal and neutral red (VRBL) bile lactose agar, inoculated in mass according to the French standard ISO 4832.

It appears that of the 190 samples; 97.4\% (185) of the results are satisfactory while $2.6 \%$ (5) of the results are unsatisfactory. The evaluation of the manufacturers of these nets indicated that there was a positive correlation between the number of serious defects and the unsatisfactory results. The result is that the best organized firms have the best laboratory results.
\end{abstract}

Citation: Doutoum AD, Tidjani A, Somda MK, Traore AS, Kallo V, Ndiaye A, et al., (2018) Search for thermotolerant coliforms in the fillets of frozen fish produced in cote d'ivoire and intended for export, GJBAHS 7: 1. doi:

Recieved date: June 01, 2018; Accepted date: June 26, 2018; Published date: June 30, 2018

Copyright: (C2018 Doutoum, et al. This is an open-access article distributed under the terms of the Creative Commons Attribution License, which permits unrestricted use, distribution, and reproduction in any medium, provided the original author and source are credited.

Competing interests: The authors have declared that no competing interest exist.

Sources of funding: No Funding.

*Email: doutoum3000@yahoo.fr; moustougounigue@yahoo.fr

\section{Keywords:}

Fish fillets, Thermotolerant coliforms, Society hygiene, Quality assurance

\section{Introduction}

In coastal countries, fishery and aquaculture products play a significant role from both an economic and social point of view. It is a source of animal protein of high nutritional value as important as meat because of its low-fat content [1].
The fisheries sector of ECOWAS and Mauritania represents more than 2 million tons of fish in 2004, $3 \%$ of world production and employs about 1 million fishermen.

Member countries' imports reached almost 1 million tons in 2003, almost half of them by Nigeria. About 400,000 tons were exported, mainly by Senegal, Mauritania and Côte d'Ivoire $(80 \%$ smoked) for a turnover of 350 billion FCFA (of which $40 \%$ for the processing segment). In Côte d'Ivoire, fishing represents, in all sectors, 
(industrial, artisanal, lagoon, maritime, etc.) between 70,000 and 100,000 tons for a consumption of 300,000 tons. The gap is filled by imports.

Indeed, in Ivory Coast, the sector accounts for 3.1\% of GDP and participates in food self-sufficiency, especially in terms of animal protein, employs a large workforce and contributes to the balance of income, payment due to exports. One of the main export markets is that of the European Union governed by a health legislation, which devotes the principle of prevention by ensuring the means and conditions of production, in addition to the quality of the safety of finished products. It is therefore essential to avoid any losses due to the withdrawal of products for non-compliance.

This is why the Ivorian health legislation lays down procedures obliging operators to fulfill the minimum conditions relating to the design of processing units and the quality of the finished product. Once the obligations of means have been respected, the controls must be carried out to assess the quality of the finished products. Thus, in Côte d'Ivoire, the Central Laboratory for Hygiene and Agro-Industry (LCHAI) performs this function through sensory analysis techniques, chemical and microbiological.

Fish fillets, which are commodities requiring many manipulations during their manufacture are very often contaminated by fecal germs. It is to contribute to the assessment of the level of contamination of these exported products that we chose this subject.

The ultimate goal of this work is to improve the hygienic quality of Ivorian fish fillets for export.

Since January 2006, the EU has requested that all laboratories analyzing fishery products have internationally recognized accreditation. This is not yet the case in Senegal and this should be a priority of the quality program.

In Ivory Coast, for example, each shipment of fish is controlled by LCHAI. Approximately 6,000 samples are analyzed each year. Controls are carried out on different forms of fish: crustaceans, fresh fish, canned fish, frozen fish, etc.

Analyzes differ by product type and standards: sensory (organoleptic) analysis for whole fresh fish, heavy metal analysis for canned tuna and chemical analysis for any product that is being handled. It should be noted that the rejection rate is less than 4\%. In addition, the EU itself validates fishing establishments in Côte d'Ivoire. The fish processing and exporting sector to the EU is highly concentrated. There are three major operators in the fishing industry for canned tuna: CASTELLI, Peach and Cold (PFCI), and Scobi. Four artisanal processing workshops are also approved for export to the EU.

Two companies are approved for the export of noble fresh fish. Companies are evaluated for equipment and hygiene conditions, and then for annual evaluations. The list of companies authorized to export is defined by ministerial decree.

The procedure is then set up at the initiative of the operator: it is the operator who must approach the state services and submit a file to present its activities. After a documentary audit and then in the field, the competent authority decides on the certification.

Once the operator is certified, the inspection services bring samples for each fish shipment to the Central Laboratory for Food Hygiene and AgroIndustry/National Laboratory for Agricultural Development Support (LCHAI/LANADA).

Thus, to meet international standards and reduce discards, fish fillet factories do self-checks but also other controls by accredited laboratories, which is why we were asked to study at the school's HIDAOA laboratory, Interstate of Sciences and Veterinary Medicine of Dakar.

\section{Material and Methods}

\section{Material}

Survey material: It consists of fact sheets.

Products analyzed: They consist mainly of frozen fish fillets from the four plants in the square. These are finished products already packed and stored in a cold room while waiting for their shipment.

Laboratory equipment: It includes one commonly used in microbiology laboratories. These elements are:

1. Sampling equipment: scissors, forceps, scalpels; 
2. Dehydrated culture medium;

3. Oven covering the temperature of $44^{\circ} \mathrm{C}$;

4. vortex agitator;

5. Bunsen burner with tripods;

6. Rack for test tube;

7. Sterilization equipment: autoclave;

8. Glassware;

9. Petri dish for single use;

10. Pallet homogenization equipment: STOMACHERND.

\section{Methods}

This study was carried out in three stages:

Survey at the level of sites or processing units of fish in net

Choice of processing units: We have chosen the units that have submitted samples to the laboratory during the last four years. These factories are four in number.

Assessment of sites by degree of non-compliance by Ababouch [1]: We used two cards; the first relates to the evaluation of construction and operating equipment, while the second is related to the assessment of industrial hygiene and operating conditions. Each of these sheets is divided into several elements to be evaluated.

These elements are in turn divided into subelements whose severity in case of non-compliance is already indicated in the form [2-10]. When visiting the facility, note for each case of noncompliance, a cross in the boxes reserved for it. If the sub-element is compliant, we will not notice anything.

Once all cases of non-compliance have been noted and their relative severity assessed, the overall assessment of the facility will be conducted. To do this, we will add all the cases of non-compliance marked in the boxes.

To get the coast of the plant, only the most severe cases will be considered. Once the factory coast is determined, we can refer to the classification table of the plants to define its category.

Retrospective study: This study consisted of collecting all the results concerning the fish fillets analyzed in the microbiology department and classifying them by company.

\section{Sample analysis}

Choice of the sample: In the course of this work, we used as some sample cartons of fillets of one kilogram or two kilograms. During the analysis, for each sample, the fillets are taken at random.

\section{Analysis}

Sampling for analysis (ISO 6887-1, 1999): Superficial and deep portions of the fish fillet were removed using sterile knives and forceps near the lit Bunsen burner.

This operation consists in taking aseptically a fraction of the flesh of fillets chosen at random until a weight of $25 \mathrm{~g}$ is obtained. The fraction thus taken is used for the preparation of the stock solution.

Stock solution and decimal dilution: The preparation of the stock solution consists of introducing the $25 \mathrm{~g}$ fraction of fillet into a sterile STOMACHERND bag. $225 \mathrm{ml}$ of buffered peptone water (PTE) are then added to obtain a stock solution (MS) titrating 1/10. Grinding and homogenization of the contents of the bag is done for 3 minutes at STOMACHERND.

This solution is allowed to stand for 40 minutes to ensure revivification. The title of this mother solution is obtained by realizing the ratio: weight of the food/total volume (diluent + food). Moreover, for very dehydrated foods we consider that their density is close to 1 , and therefore $1 \mathrm{~g}$ of food equals a volume of $1 \mathrm{ml}$.

\section{Enumeration of fecal coliforms (I.S.O 1978)}

Preparation of the culture medium (VRBL): $38 \mathrm{~g}$ of powder of the complete medium dehydrated in $1 \mathrm{~L}$ of distilled water previously heated to $100^{\circ} \mathrm{C}$ for 10 minutes and then brought to the laboratory temperature. After 5 minutes, we mix until a homogeneous suspension is obtained. Then it is heated slowly, adding frequently, until boiling and complete dissolution. Then, $\mathrm{pH}$ is adjusted to 7.4. The medium is used in the hours following its preparation. Before use, the medium is in a bath at $48^{\circ} \mathrm{C}+$ or $-1^{\circ} \mathrm{C}$.

Seeding: $1 \mathrm{ml}$ of the stock solution is transferred to the center of each petri dish using a pipette, bringing the end of the pipette into contact with the dry surface of the can. 
Agar distribution: About $12 \mathrm{ml}$ of VRBL agar at $45^{\circ} \mathrm{C}+$ or $-1^{\circ} \mathrm{C}$ is poured into the seeded dish. It is mixed immediately after pouring the agar, by rotating the petri dish to obtain a regular distribution of colonies after incubation. It is allowed to solidify on a cool, horizontal surface. Then, a control box with $1 \mathrm{ml}$ of the medium is prepared to control its sterility. After complete solidification of the medium, the surface of the seeded medium will flow to about $4 \mathrm{ml}$ of the medium VRBL at $45^{\circ} \mathrm{C}+$ or $-1^{\circ} \mathrm{C}$. and allowed to solidify.

Incubation: During this phase the boxes are put in the oven, in the inverted position. The temperature of the oven is set at $44^{\circ} \mathrm{C}$. This operation lasts 24 hours.

Counting (ISO 4832) (5): Dark red colonies with a diameter of at least $0.5 \mathrm{~mm}$ characteristic of coliforms are counted.

Expression of results: The number of coliforms per gram is equal to:

$\Sigma \mathrm{c}=$ sum of colonies of successively counted boxes

$\mathrm{V}=$ dilution volume used

$\mathrm{n} 1=$ number of boxes in the first dilution

$\mathrm{n} 2=$ number of boxes in the second dilution

$\mathrm{d}=$ dilution factor

For counting, keep the boxes containing more than 10 and less than 150 colonies. If the number is less than 10 , it is indicated that the number of coliforms per gram is "less than $10 \mathrm{Xd}$ ". If it is greater than 150 , the number of colonies is multiplied by the inverse of the division factor. This result is expressed in "estimated number of coliforms per gram". The standard used is $\mathrm{m}=20$ coliform per gram.

The quality of a lot is considered as:

For the counting, the satisfactory when will be retained when the observed value is less than or equal to $3 \mathrm{~m}$;

Acceptable when the observed value is between 3 $\mathrm{m}$ and $10 \mathrm{~m}$; Unsatisfactory when the observed value is greater than $10 \mathrm{~m}$.

\section{Results and discussion}

\section{Results}

Assessment of companies by degree of noncompliance

Table 1: Classification of facilities by degree of noncompliance.

\begin{tabular}{llllll}
\hline $\begin{array}{l}\text { Comp } \\
\text { anies }\end{array}$ & $\begin{array}{l}\text { Critical } \\
\text { defects }\end{array}$ & $\begin{array}{l}\text { Serious } \\
\text { faults }\end{array}$ & $\begin{array}{l}\text { Major } \\
\text { defects }\end{array}$ & $\begin{array}{l}\text { Minor } \\
\text { defects }\end{array}$ & $\begin{array}{l}\text { Catego } \\
\text { ries }\end{array}$ \\
\hline I & 0 & 6 & 14 & 3 & D \\
\hline II & 0 & 1 & 3 & 0 & B \\
\hline III & 0 & 3 & 9 & 2 & C \\
\hline IV & 0 & 11 & 12 & 3 & D \\
\hline Total & 0 & 21 & 38 & 59 & \\
\hline
\end{tabular}

Table 1 indicates that there are no critical faults. However, major, minor and serious defects vary from one society to another. In general, the most important defects in number are represented by the major defects followed by the serious defects. The serious defects vary between 11 for company IV and 01 for company II. Major defects vary between 14 (company I) and 03 (company II).

The largest number of defaults is found at company IV followed by company I. This makes it possible to classify these 2 companies in category D. Societies II and III for their part are respectively in categories $\mathrm{B}$ and $\mathrm{C}$ according to Ababouch, [1].

The factory code is obtained by adding the cases of non-conformity marked by a cross in the boxes of Tables 2 and 3. This operation allowed us to classify the factories according to the number of serious defects and to categorize them.

\section{Result of bacteriological analyzes}

Overall results: The results are expressed in "estimated number of coliforms per gram". The standard used is $\mathrm{m}=20$ coliform per gram according to the International Commission on Microbiological Standards.

The quality of a lot is considered as:

Satisfactory when the observed value is less than or equal to $3 \mathrm{~m}$; Acceptable when the observed value 
is between $3 \mathrm{~m}$ and $10 \mathrm{~m}$; Unsatisfactory when observed value is greater than $10 \mathrm{~m}$.
Number of samples per year: Over the period from 2011 to 2014, the central laboratory for hygiene and agribusiness registered 190 samples (Table 4).

Table 2: Evaluation of construction and operating equipment.

\begin{tabular}{|c|c|c|c|c|c|c|c|c|c|c|c|c|}
\hline \multirow[t]{2}{*}{ Elements to inspect } & \multicolumn{4}{|c|}{ Major } & \multicolumn{4}{|c|}{ Minor } & \multicolumn{4}{|c|}{ Serious } \\
\hline & I & II & III & IV & I & II & III & IV & I & II & III & IV \\
\hline 1. Design of fish workplaces & $*$ & & & & & & & & & & & \\
\hline - Sufficient surface to work & & & * & & & & & & & & & \\
\hline - No-intersecting circuits & & & & $*$ & & & & & * & & & $*$ \\
\hline
\end{tabular}

\section{Fish workplaces}

2.1 Soils: Flow and evacuation

2.2 walls

2.3 ceilings

- easy to clean

2.4. Doors

- easy to clean

2.5. Ventilation

- Adequate

- Good evacuation steam

2.6. Lighting

2.7. No-hand disinfection

- Devices in sufficient numbers

3. Fish workplaces

3.1. Floors: Easy drainage and evacuation

3.2. walls

- Clear, smooth surfaces, easy to clean

3.3. ceilings

- easy to clean

3.4. Doors

- easy to clean

3.5. Lighting

3.6. Sufficient cooling capacity

4. Protection against vermin

- Appropriate devices

5. Work tools 
6. Disposal of fishery products not intended for human consumption

- Watertight waste containers made of corrosion-resistant materials

- Adequate local

7. Water supply

8. Waste water

9. Cloakrooms and cabins of ease

- Number of appropriate locker rooms

- Suitable number of washbasin

- Appropriate number of lavatories

10. Premises for inspection service

11. ND means of transport

- Appropriate equipment

12. Installation for living products

13. Freezing and storage facility

Table 3: Assessment of industrial hygiene and operating conditions.

\section{Elements to inspect}

\begin{tabular}{llllllllllll}
\multicolumn{1}{c}{ major } & \multicolumn{4}{c}{ Minor } & \multicolumn{4}{c}{ Serious } \\
\hline I & II & III & IV & I & II & III & IV & I & II & III & IV
\end{tabular}

\section{General conditions of hygiene}

1.1. Premises and equipment

- Maintained in good condition of ownership and maintenance

1.2 Staff hygiene

- Prohibit any person from contaminating the product from handling

- Wearing clothes

\section{Container and fresh products}

- Protects products against contamination

\section{Fresh products}

- Iced products are regularly regulated

- Threading and slicing in a different location than for heading and gutting

\section{Thawed products}

- Hygienically

- Appropriate temperature 
Of the 190 samples, 185 have an average number of germs of less than 10 (6) germs per gram (7) or $97.4 \%$

The other 5 have an average number of seeds greater than 10 per gram $(2.5 \times 102)$, therefore unsatisfactory.

Table 4: Samples analyzed by company.

\begin{tabular}{lll}
\hline Society & $\begin{array}{l}\text { Number } \\
\text { samples }\end{array}$ & of Percentage (\%) \\
\hline I & 41 & 21,6 \\
\hline II & 59 & 31,1 \\
\hline III & 44 & 23,2 \\
\hline IV & 46 & 24,1 \\
\hline Total & 190 & 100 \\
\hline
\end{tabular}

The fish species used: The laboratory recorded 16 different species over the 4 years (Table 6).
According to Table 5, Company II sent to the laboratory the largest number of samples, ie $31 \%$ (59), followed by companies IV, III and I.

Table 5 shows that red mullet is the most widely used fishmonger with $27.9 \%$ (53). It is followed by sole with a percentage of $25.8 \%$ (49). Then comes the mostelle with a percentage of $16.3 \%$ (31). Species such as scorpionfish, saint-pierre and tilapia are used very little (less than $1 \%$ ).

Table 5: Overall Results of Microbiological Analyzes.

\begin{tabular}{lll}
\hline Society & $\begin{array}{l}\text { Satisfactory } \\
\text { results }\end{array}$ & Unsatisfactory results \\
\hline I & 40 & 1 \\
\hline II & 58 & 1 \\
\hline III & 43 & 1 \\
\hline IV & 44 & 2 \\
\hline Total & 185 & 5 \\
\hline
\end{tabular}

Table 6: Fish species used for net manufacturing in Ivory Coast.

\begin{tabular}{|c|c|c|}
\hline Especie & Number of fish & Percentage (\%) \\
\hline Triggerfish & 7 & 3.7 \\
\hline Bar & 12 & 6.3 \\
\hline dolphinfish & 4 & 2.1 \\
\hline Swordfish & 7 & 3.7 \\
\hline poleaxe & 5 & 2.7 \\
\hline Grouper & 2 & 1.0 \\
\hline Mostelle & 31 & 16.3 \\
\hline scorpion fish & 1 & 0.5 \\
\hline Shark & 4 & 2.1 \\
\hline Red mullet & 53 & 27.9 \\
\hline Sole & 49 & 25.8 \\
\hline Saint Pierre & 1 & 0.5 \\
\hline Tuna & 6 & 3.1 \\
\hline tilapia & 1 & 0.5 \\
\hline
\end{tabular}




\begin{tabular}{llc}
\hline Tom & 2 & 1.1 \\
\hline Zebra & 5 & 2.7 \\
\hline TOTAL & 190 & 100
\end{tabular}

\section{Results by company}

Company 1: This company sent 41 samples for 2 years and the results are shown in Table 7.

Table 7: Samples and results of company I.

\begin{tabular}{lllll}
\hline Year & $\begin{array}{l}\text { Quan } \\
\text { tity }\end{array}$ & $\begin{array}{l}\text { Percentage } \\
\%\end{array}$ & Results in CFU / gram \\
\cline { 3 - 5 } & & & Satisfactory & $\begin{array}{l}\text { Not } \\
\text { satisfying }\end{array}$ \\
\hline 2012 & 40 & 97.6 & $6(40)$ & 0 \\
\hline 2013 & 1 & 2.4 & 0 & $2,6.102(1)$ \\
\hline Total & 41 & 100 & 40 & 1 \\
\hline
\end{tabular}

Table 7 shows that, the average values of their faecal coliform abundance are 6 and 2.6.102 ufc/g successively in the samples of the year 2012 and 2013.

Or

$97.6 \%$ (40) of the results are satisfied and 2.4\% (1) unsatisfactory.

Company 2: This company sent 59 samples for 3 years and the results are shown in Table 8 .
According to Table 8, it was in 2012 that Company II sent the largest number of samples (55.9\%) while it was absent from the register in 2013. All these samples are satisfactory to the except for 2012 .

Table 8: The samples and the results of the company II.

\begin{tabular}{lllll}
\hline Year & $\begin{array}{l}\text { Quant } \\
\text { ity }\end{array}$ & $\begin{array}{l}\text { Percenta } \\
\text { ge \% }\end{array}$ & \multicolumn{2}{l}{ Results in CFU/gram } \\
\cline { 4 - 5 } & & Satisfactory & $\begin{array}{l}\text { Not } \\
\text { Satisfying }\end{array}$ \\
\hline 2011 & 11 & 18,6 & $6(11)$ & 0 \\
\hline 2012 & 33 & 55,9 & $7(32)$ & $2,5.102(1)$ \\
\hline 2014 & 15 & 25,4 & $5(15)$ & 0 \\
\hline $\begin{array}{l}\text { TOTA } \\
\text { L }\end{array}$ & 59 & 100 & 58 & 1 \\
\hline
\end{tabular}

The average values of faecal coliforms are 6,7 and $5 \mathrm{ufc} / \mathrm{g}$ respectively in the samples of 2011, 2012 and 2014.

Company 3: This company brought 44 samples for 3 years (Table 9 ).

Table 9: The result and samples of society III.

\begin{tabular}{lllll}
\hline Year & Quantity & Percentage $\%$ & Results in CFU/gram & \\
\cline { 3 - 5 } & & & Satisfactory & Not Satisfying \\
\hline 2012 & 21 & 47,7 & $7(20)$ & $2,4.102(1)$ \\
\hline 2013 & 16 & 36,4 & $6(16)$ & 0 \\
\hline 2014 & 7 & 15,9 & $5(7)$ & 0 \\
\hline Total & 44 & 100 & 43 & 1 \\
\hline
\end{tabular}

The largest number of samples was recorded in 2012 with $47.7 \%$. Out of a total of 44 samples, we obtained $97.7 \%$ (43) satisfactory results and 2.3\% (1) unsatisfactory results. 
Company 4: This company brought 46 samples during 4 years (Table 10).

Table 10: The results and samples of the company VI.

\begin{tabular}{lllll}
\hline Year & Quantity & Percentage $\%$ & Résults in CFU/gram & Not Satisfying \\
\cline { 3 - 5 } & & & Satisfactory & 0 \\
\hline 2011 & 4 & 8,7 & $6(4)$ & $2,6.102(1)$ \\
\hline 2012 & 8 & 17,4 & $5(7)$ & 0 \\
\hline 2013 & 24 & 52,2 & $7(24)$ & $2,5.102(1)$ \\
\hline 2014 & 10 & 21,7 & $6(9)$ & 2 \\
\hline
\end{tabular}

Table 10 shows that of the 46 samples analyzed, $95.7 \%$ (44) were satisfactory and $4.3 \%$ (2) unsatisfactory.

In general, all 4 companies have fairly satisfactory products. But given the competition, these products must be treated in a more hygienic way by avoiding as much as possible the critical points (Table 11 and Figure 1).

Table 11: Relationship between number of defects and unsatisfactory results.

\begin{tabular}{llll}
\hline Society & $\begin{array}{l}\text { Serious } \\
\text { faults }\end{array}$ & $\begin{array}{l}\text { Satisfactory } \\
\text { results }\end{array}$ & $\begin{array}{l}\text { Unsatisfactory } \\
\text { results }\end{array}$ \\
\hline I & 6 & 40 & 1 \\
\hline II & 1 & 58 & 1 \\
\hline III & 3 & 43 & 1 \\
\hline IV & 11 & 44 & 2 \\
\hline Total & 21 & 185 & 5 \\
\hline
\end{tabular}

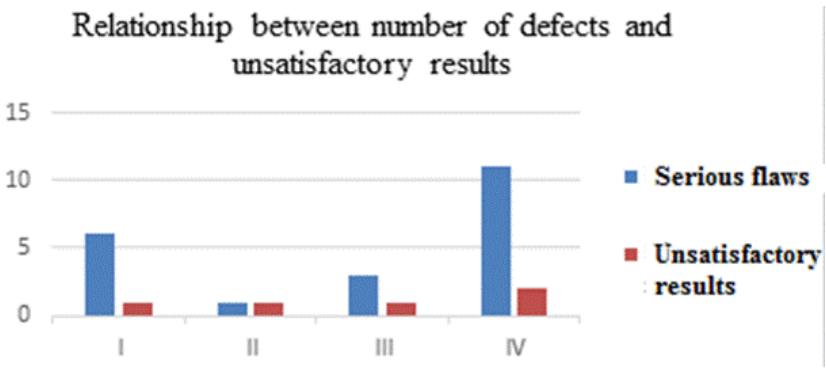

Figure 1: Graph showing positive correlation between the number of serious defects and unsatisfactory results.
We find that there is a positive correlation between the number of serious defects and unsatisfactory results. Companies with the highest number of serious defects have the highest percentages of unsatisfactory results. Thus, the best organized companies have the best laboratory results.

\section{Discussion}

As for the total number of samples for the 4 years, it is 190 . The sample size is very large given the packaging that contains many fish fillets [11-13]. Then, the four Ivorian companies often practice self-monitoring to meet the standards of the European Union. Finally, they also send samples to regional microbiological fish testing laboratories [14]. Collected 600 samples in a single year in Senegal, where this sector has grown significantly [15-22]. The species used in making fish fillets are mainly red mullet, sole and broth. Our results are similar to those of Cote d'Ivoire except that the brotules are replaced by the mostelles [23-37]. Our results are comparable to those found by Seydi, et al. [38] in Senegal. Because these authors use mainly soles and brotules the two main fish species exploited in the making of frozen fillets. They used only one type of fish for their study, namely Mugil cephalus, and obtained a high level of contamination of 180 germs per gram of coliforms. Our results gave a satisfaction rate of $97.4 \%$ and a non-satisfaction rate of $2.6 \%$. Our results are in line with those of Baer, et al. [7] who found a contamination rate of between 1 and 10 germs per gram of product. Five samples out of 90 , which is $2.6 \%$ are unsatisfactory but are in deca of those 
found by Seydi, et al. [38] who found results much higher on the order of $31.87 \%$ [39-41]. Toure [42] found results of noncompliant nets of the order of $9.49 \%$, these results are similar to ours. It is noted that in Senegal microbiological analyzes have no doubt been improved with the introduction of the HACCP system at the level of all companies processing fish products from 1996 by Baer [7]. Other authors, such as Ndiaye [31] in 1996 and 1997 and Sitti [40] from 1997 to 2000 on the evolution of the bacteriological quality of fishery products for export showed that there is a significant decrease in thermotolerant coliforms over the years, which indicates a significant improvement in compliance with hygiene rules and good manufacturing practices in processing plants for fish products. Indeed, according to the following authors Ababouch [1], Borner [9], Chandraval, et al. [10], Degnon, et al. [12], Dib amira [13], Fleming [16], Tsamba [43], thermotolerant coliforms, which are present in the food, are witnesses of the non-respect of the rules of hygiene (faecal contamination of the products). This favorable evolution of food quality is undoubtedly the result of the introduction of the Hazard Analysis Critical Control Points (HACCP) or Hazard Analysis and Critical Control Point (ADMPC) system at the level of all processing companies. fishery products from 1996. Have an average of 69 germs/ g against 236 germs/ g depending on the culture medium used. These authors, whatever the medium, have found results far superior to ours. They explain these high values by the fact that the products came into contact with many critical points. For Ndiaye [31] 111 samples out of 112 gave numerical results with an average of 236 germs per $\mathrm{g}$ of net. This average is much higher than ours and as well as that obtained by Baer quoted by Seydi, et al. [39] or between 1 and 10 germs $1 \mathrm{~g}$ of product. The average we obtained, however, is much lower than that obtained by Seydi et al. [38] or 625 seeds per $\mathrm{g}$ of net. In addition, Seydi, et al. [39], Toure [42] and also found higher values of the order of 275 sprouts/ g net. These results were obtained before the actual implementation of the HACCP system. Azibe [5], Ouattara [32] find very different results. The first reports an average contamination of 625 germs / g while the second finds an average of 12 germs/ $\mathrm{g}$, have shown in their work that the fertility of coliforms depends on the culture medium used: some are very fertile and allow a large count while others are not very fertile and cause a low rate of coliforms, which is a bias that explains in part the disparity in the results obtained. In contrast, the processing units we evaluated did not implement any HACCP system and therefore did not develop a real sampling plan. These producers may have prepared special samples for analysis and this will not reflect the microbiological quality of the lot. To this end, Huss $[21,22]$ states that the number, size and nature of the samples greatly influence the results obtained. Numerous faecal coliforms have been enumerated massively in the Fresco lagoons Kouadio, et al. [27]. Many authors around the world, whatever the measures implemented, have also observed thermos tolerant coliforms on fish analyzes [Alves Guerreiro [4], Badri, et al. [6], Dib Chandraval, et al. [10], Amira [13], El Afly [15], Fleming, et al. [16], Ghanem, et al. [17], Grant, et al. [19], Ip [23], Polimetla, et al. [34], Teophilo, et al. [41,44], Tsamba [43]]. Thermos tolerant coliforms are not always adapted to the high temperature of $44^{\circ} \mathrm{C}$ because many authors have identified them in fish incubated at very low temperatures of times below $30^{\circ} \mathrm{C}$ by Albuquerque [2], Chapot-Chartier, et al. [11], Wounter, et al. [45]. The results obtained on fish fillets vary from one technique to another. Current methods based on genetics make it possible to detect bacteria that would have gone unnoticed by culture, biochemical and microscopic methods [Almeida, et al. [3], Badri, et al. [6], Bennani [8], Chapot-Chartier, et al. [11], Gourmelon [18], Kumar, et al. [28], Mayo, et al. [30], Park [33], Ryu, et al. [35], Sauvageot, et al. [36], Wounter, et al. [44]]. Finally, some thermos tolerant coliforms are insensitive to certain drug substances [Ip [23], Jeyasanta, et al. [26], Park, et al. [33].

\section{Conclusion}

In Ivory Coast, as in most coastal countries, fish production plays a significant role both economically and socially. It participates in the balance of the trade balance thanks to the inflows of currencies consecutive to exports. Many companies have started this activity, given the growing demand. Also, among fish commodities, the net is one of the most popular products on the international market. However, its entry into this market is dependent on the satisfaction of certain microbiological criteria. Its production is especially marked by a mechanization can push factories. The 
consequence is a strong manipulation of the products by the staff, a source of frequent contamination by thermos tolerant coliforms. That's why we started looking for these microbes in fish fillets for export. The purpose of this work was to assess their level of contamination. To do this, we conducted technical visits to four companies producing these commodities, and we conducted a retrospective analysis of the results of the analyzes for these germs in fish fillets from 2011 to the first half of 2014. From this study bacteriological, it appears that $97.4 \%$ of the samples are satisfactory and that $2.6 \%$ are unsatisfactory. Thus, to get closer to the requirements of the European Union in terms of quality assurance and preserve or even acquire new markets for products for export; it would be essential to undertake a set of actions to acquire the legal, human and technical means necessary for the establishment of a national inspection and quality assurance program.

\section{References}

1. Ababouch L. Quality assurance in the fishing industry. Rabat: (edn). ACTS, 1995-214p

2. Albuquerque CR. Escherichia coli in seafood: A brief overview. Advances in Bioscience and Biotechnology. 2013;4:450-454.

3. Almeida C, Sousa JM, Rocha R, Cerqueira L, Fanning S, Azevedo NF, et al. Detection of Escherichia coli O157 by peptide Nucleic Acid Fluorescence in Situ Hybridization (PNA-FISH) and Comparison Standard Culture Method. Applied and Environmental Microbiology. 2013;79(20): $1-8$.

4. Alves Guerreiro. Anàlise molecular e fenotipica da virulência em estirpes de Escherichia coli isoladas de alimentos prontos-acomer (RTE). Instituto Superior de Agronomia. Univers dade Técnica de Lisboa. Dissertaçao para a obtençao do Grau de Mestre em Engenharia Alimentar-Qualidade e Segurança Alimentar. 2012;25:109.

5. Azibe M. Contribution to the study of parasitological, chemical and bacteriological quality of frozen fish fillets produced in Senegal. Th Med Vet Dakar. 1991;19:.

6. Badri S, Filliol I, Carle I, Hassar M, Fassouanec A Prevalence of virulence genes in Escherichia coli isolated from food in Casablanca (Morocco). Food Control. 2009;20(6):560-564.

7. Baer EF, Duran AP, Leiniger HV, Read RB. Microbiological quality of frozen breaded fish and shellfish products. App Environ Microbiol. 1976;31(3): 337-341.

8. Bennani M, Badri S, Baibai T, Oubrim N, Hassar M, Cohen N, et al. First Detection of Shiga Toxin-Producing Escherichia coli Shellfish and Coastal Environments of Morocco. Applied Biochemistry and Biotechnology. 2009;165(1):290-299.
9. Borner. The main germs of faecal contamination and indicators encountered mainly in foods intended for humans. Int j Biol Chem Sci. 2000;6(1):166-174.

10. Chandraval D, Debasish S, Ashis Kumar P, Chandan S. The occurrence of Escherichia coli in fish samples isolated from different ponds of Nadia District, West Bengal, India. Internet Journal of Food Safety. 2010;12:181-186.

11. Chapot-Chartier MP, Schouler C, Lepeuple AS, Gripon J, Chopin MC. Characterization of cspB, a cold-shockinducible gene from Lactococus lactus, and evidence for a family of genes hornologous to the Escherichia coli cspA major cold shock gene. Journal of bacteriology. 1997;179:5589-5593.

12. Degnon GR, Dougnon TS, Toussou S, Mignan ET. Assessment of the microbiological and physicochemical quality of the fish caught and marketed at the industrial fishing port of Cotonou. Int J Biol Chem Sci. 2012;6(1): 166-174.

13. Dib Amira L. Microbial evaluation of seafood. Doctorate in food hygiene Constantine-Algeria. 2014;280.

14. AA ; BADA-ALAMBEDJI ; AMAR OMN et SEYDI $\mathrm{Mg}$ (2003). Comparative study of the fertility of two VRBL culture media of different origin, used to search for thermotolerant coliforms in frozen fish fillets RASPA. 2003;(3):108-112.

15. El Afly MS, Ahmed S, Selim S, Abdel Aziz MH, Zakaria A, Klena JD. Prevalence and characterization of Shiga toxin $\mathrm{O} 157$ and non-O 157 enterohemorrhagic Escherichia coli isolated from different sources in Ismailia. African Journal of Microbiology Research. 2013;7(21):2637-2645.

16. Fleming A. Food poisoning (TIAC) in the Rhône-Alpes region: review and analysis of causes. Operational management of a suspicion of TIAC by a departmental directorate of the (social cohesion and) protection of populations (DD (CS) PP): example in the department of Loire. Thesis Med Vet Lyon-France. 2014;106.

17. Ghanem NA, Elshabassy NA, Hai E, Samaha IA. Enterobacteriaceae in Some Marine Fish. Alexandria Journal of Veterinary Sciences. 2014;40(1):124-131.

18. Gourmelon M, Montet MP, Lozach S, Le Mennec C, Pommepuy M. First isolation of Shiga toxin 1d producing Escherichia coli variant strains in shellfish from coastal areas in France. Journal of Applied Microbiology. 2006;100(1):85-97.

19. Grant MA, Hedberg C, Johnson R, Harris J, Logue MC, Jianghong $\mathrm{M}$, et al. The significance non O 57 Shiga toxin-producing Escherichia coli in food Food Protection Trends. 2011;31:33-45.

20. Huss H. Quality assurance of seafood. Rome : FAO / DANIDA. 1996;158p.

21. Huss H. Quality and its evolution in fresh fish. FAO Fisheries Technical Paper. 1999;T348:198p.

22. Huss HH, Gram L. Characterization of Hazards in Seafood Assurance of Seafood Quality. FAO Fisheries Technical Paper. 2004;444:26-52.

23. Institut Pasteur.2012, Escherichia Coli Institut Pasteur https://www.pasteur.fr/fr/institut-pasteur/presse/fichesinfo/escherichia-coli.Consultél le 19/03/14 
24. ISO 6887-1. 1999, Microbiology of food preparations Preparation of test samples, initial suspension and decimal dilutions for microbiological examination-Part 1: General rules for the preparation of the initial suspension and decimal dilutions.

25. I.S.O (1978), General guidelines for enumeration of coliforms-colony counting methods obtained. I.S.O, 1978-130p.

26. Jeyasanta KI, Aiyamperumal Patterson J. Prevalence of Antibiotic Resistant Escherichia coli in Sea Foods of Tuticorin Coast, Southeastern India. Advanced Biological Research. 2012;6(2):70-77.

27. Kouadio N, Dadie A, Adingra A, Ake Y, Dje K. Biotypes of Escherichia coli isolated from fish and water from the Fresco Lagoon, Ivory Coast. Applied Biosciences Journal. 2011;38:2523-2530.

28. Kumar HS, Otta SK, Karunasagar I, Karunasagar. Detection of Shiga-toxigenic Escherichia coli (STEC) in fresh seafood and meat marketed in Mangalore, India by PCR. Letters in Applied Microbiology. 2001;33:34-338.

29. Marceau A, Zagorec M, Chaillon S, Mera T, ChamponierVerges MC. Evidence of involvement of at least six protein in adaptation of Lactobacillus sakei to cold temperature and addition of Nacl. Applied \& Environmenal Microbilology. 2004;70:7260-7268.

30. Mayo B, Derzelle S, Fernandez M, Leonard C, Ferain T, Hols $\mathrm{P}$, et al. Cloning characterization of cspL and cspP, two cold-inducible gene from Lactobacillus plantarm. Journal of Bacteriology. 1997;179:3039-3032.

31. Ndiaye A. Contribution to the study of the evolution of bacteriological quality of fishery products destined for export from 1996 to 1997. Th Med Vet Dakar. 1998;17.

32. Ouattara B. Study of the bacteriological quality of frozen fish fillets. Th Med Vet Dakar. 1986;20.

33. Park KS. Antimicrobial Resistance and Virulence genes presence in E. coli strains isolated from Gomso Bay. Korea Fish Aquatic Science. 2013;16(4):221-227.

34. Polimetla B. Prevalence of Escherichia Coli in food fishes assessed from domestic retail fish market, Guntur City, Andhra Pradesh, India: A case study. International Journal of Engineering Science and Technology. 2013;5(7): 1545-1552.

35. Ryu SH, Park SG, Choi SM, Hwang YO, Ham HJ, Kim $\mathrm{SU}$, et al. Antimicrobial resistance and resistance genes in
Escherichia coli strains isolated from commercial fish and seafood. International Journal of Food Microbiology. 2012;152(1-2):14-18.

36. Sauvageot N, Beaufils S, Maze A, Deutscher J, Hartke A. Cloning and characterization of gene encoding a coldshock protein in Lactobacillus casei, FEMS. Microbiology Letters. 2004;254:55-62.

37. Serror P, Dervyn R, Ehrlich SD, Maguin E. Csp-like genes of Lactobacillus delbrueckii ssp bulgaricus and their response to cold shock. FEMS. Microbiology Letters. 2003;226:323-330.

38. Seydi MG, Pangui L, Azibe M. Hygienic quality of frozen fish fillets produced in Senegal. Rev Microb. $1992 ; 9(4)$ : 12-17.

39. Seydi MG, Ndao D, Minl'a Mi Oyono JC. Study of the level of implementation of the HACCP system in fishery products companies in Senegal. Microb Hyg Ali. 2001;13(6):1-12.

40. Sitti AH. Contribution to the study of the evolution of bacteriological quality of fishery products destined for export from 1997 to 2000. Th Med Vet Dakar. 2001;17.

41. Teophilo G, Fernandes Vieira RD, Prazeres Rodrigues DD, Menezes RR. Escherichia coli isolated from seafood:toxicity and plasmid profiles. International Microbiology. 2002 ;5(1):11-14.

42. Toure MH (1996). Contribution to the study of coliform contamination of Senegalese fish fillets for export. Th Med Vét Dakar. 1996;17.

43. Tsamba Moussosso A. Effects of cold on the bacteriological quality of sole fillets elaborated in a fishing industry in Senegal. Memory for obtaining the Master 2 in quality of food for the Man. Dakar-Senegal 2010;17.

44. Wounter JA, Sander JW, Kok J, De Vos WA, Kuipers OP, Abee T. Clustered organization and transcriptional analysis of a family of five csp genes of Lactobacillus lactis MG 1363. Microbiology. 1998;144:2885-2893.

45. Wounter JA, Rombouts FM, De Vos WM, Kuipers OP, Abee T. Cold shock proteins and low-temperature of Streptococcus thermophilus CNRZ 302. Applied and Environmental Microbiology. 1999;65:4436-4442. 